\title{
Dietary Energy Budgets in Carp
}

\author{
Masahiro Ohta*1 and Takeshi Watanabe*2 \\ ${ }^{*_{1}}$ Aquaculture Research Center, Nippon Formula Feed Mfg. Co., Ltd., \\ Oozima, Yaizu, Shizuoka 425, Japan \\ ${ }^{* 2}$ Laboratory of Fish Nutrition, Tokyo University of Fisheries, \\ Konan, Minato, Tokyo 108, Japan
}

(Received March 4, 1996)

\begin{abstract}
Dietary energy budgeting in carp was studied based on the energy requirements for maintenance of body weight and activity, and for maximum growth. Budgeting was determined by analyzing the whole body composition of carp and measuring the digestible and metabolizable energy values (DE and ME) of diets. Fish having a mean initial weight of 243.2 and $5.6 \mathrm{~g}$ were fed an experimental casein diet, and those of $3.9 \mathrm{~g}$ were fed a practical type of fish meal diet for 14 or 19 days, respectively.

The energy partitionings of these diets based on gross energy (GE) intake $(100 \%)$ at the level required for maximum growth were: $16.7-29.9 \%$ lost as fecal energy, $1.5-2.0 \%$ as non-fecal energy, $31.9-38.9 \%$ as heat increment, and $36.7-43.2 \%$ as net energy $(12.6-15.5 \%$ as net energy for maintenance and activity and $24.1-27.7 \%$ as productive energy). The proportion of fecal energy value was relatively high and was greatly influenced by the quality of the diet, and the heat increment of feeding was found to occupy a large portion of the energy budgets in fish.

The non-fecal energy loss increased proportionally to the DE intake. The non-fecal energy/DE rate was inversely related to the DE intake in fish receiving DE less than the maintenance requirement of fish body, but above this DE intake, the proportion remained constant.
\end{abstract}

Key words: energy budget, heat increment, maintenance and activity, carp

In animals the chemical energy supplied in food is constantly being converted to free energy coupled with the release of energy as heat. Animals use the energy organized by the catabolism of food to sustain the life process. The energy of diets and feedstuffs of mammals has been investigated by many researchers. ${ }^{1)}$ It is also recognized that the interactions between nutrients and the dietary energy cost are of great importance.

Generally speaking, protein and lipid are utilized more effectively than carbohydrate as energy sources in fish, although lipid and carbohydrate are used as the main energy sources in terrestrial animals. Fish is a poikilothermic animal and several studies have been conducted to elucidate their nutritional energetics, but thorough investigations on energy budgets of diet are few. ${ }^{2,3)}$ This is due to the difficulty in determining the metabolizable energy values of diets because of the need to quantify the energy losses across the gills and in urine.

In this series of studies on nutritional energetics in carp and rainbow trout, ${ }^{4,5)}$ endogenous nitrogen excretion and non-fecal energy losses were already clarified using the system developed by Ogino et al., ${ }^{6}$ together with digestible and metabolizable energy of various diets, to obtain basic data necessary for standardization of feed quality evaluation for fish in captivity with special emphasis on their energy requirements. In addition, energy requirements for maintenance of body weight and activity, and for maximum growth were also determined with rainbow trout by feeding them quality experimental fish meal diets and a commercial diet at different feeding levels.")

Following the previous experiments, this study was con- ducted to calculate dietary energy budgets in carp by feeding different sizes of fish with experimental casein diets and a practical type of diet. Energy requirements for maintenance of body weight and activity, and for maximum growth of carp were also determined.

\section{Materials and Methods}

\section{Experimental Diets}

Three feeding experiments (Experiments I-III) were conducted using different sizes of fish. The same experimental diet containing casein as a protein source and a mixture of soybean oil and pollock liver oil (3:2) as lipid source was used in Expts. I and II. The formulation and proximate composition of the casein diet are listed in Table 1. The casein diets prepared twice in Expts. I and II contained 31.1 and $32.6 \%$ crude protein, $5.3 \%$ lipid, and 4.49 and $4.54 \mathrm{kcal} / \mathrm{g}$ in $\mathrm{GE}$, respectively and seemed to provide sufficient amounts of protein and DE to meet the requirements of carp. ${ }^{8)}$

The composition of the experimental diet used in Expt. III is presented in Table 2. The diet was prepared using practical ingredients and was the same as that used in a previous experiment. ${ }^{5)}$ This diet contained $39.7 \%$ crude protein, $10.9 \%$ lipid, and $4.73 \mathrm{kcal} / \mathrm{g}$ in GE.

\section{Culture Conditions and Collection of Fecal and Urinary} Nitrogenous Compounds

At the end of preliminary feeding (described previous$\left(y^{7}\right)$, fish were starved for one day and their body weight was determined individually in the morning. Thereafter 
Table 1. Composition of the diet used for Expts. I and II

\begin{tabular}{lc}
\hline \multicolumn{1}{c}{ Ingredients } & $(\%)$ \\
\hline Casein & 35 \\
$\alpha$-Starch & 15 \\
Dextrin & 23 \\
Lipid ${ }_{1}$ & 5 \\
Cellulose & 14 \\
Mineral mixture & 5 \\
Vitamin mixture & 2 \\
$\mathrm{Cr}_{2} \mathrm{O}_{3}^{* 2}$ & 1 \\
\hline
\end{tabular}

\begin{tabular}{lrr} 
& \multicolumn{2}{c}{ Experiment } \\
\cline { 2 - 3 } & I & II \\
\hline Moisture & 7.2 & 6.2 \\
Crude protein & 31.1 & 32.6 \\
Crude lipid & 5.3 & 5.3 \\
Gross energy (kcal/g) & 4.5 & 4.5 \\
\hline
\end{tabular}

* Soybean oil:pollock liver oil $=3: 2$, containing $1 \% \mathrm{dl}-\alpha$-tocopheryl acetate.

*2 $\mathrm{Cr}_{2} \mathrm{O}_{3} ;$ cellulose $=1: 1$.

Table 2. Composition of the diet used for Expt. III

\begin{tabular}{lc}
\hline \multicolumn{1}{c}{ Ingredients } & $(\%)$ \\
\hline Fish meal & 25 \\
Meat meal & 4 \\
Soybean meal & 10 \\
Corn gluten meal & 8 \\
Wheat flour & 35 \\
Defatted rice bran & 9.5 \\
NaH $\mathrm{PO}_{4}$ & 2.5 \\
Mineral mixture & 0.5 \\
Vitamin mixture & 0.5 \\
Yellow grease & 4 \\
Soybean oil & 1 \\
Sodium propionate & 0.4 \\
Ethoxyquin & 0.015 \\
Cr $\mathrm{O}_{3}^{*}$ & 1 \\
\hline Moisture & 3.8 \\
Crude protein & 39.7 \\
Crude lipid & 10.9 \\
Gross energy $(\mathrm{kcal} / \mathrm{g})$ & 4.73 \\
\hline
\end{tabular}

* $\mathrm{Cr}_{2} \mathrm{O}_{3}$ :cellulose $=1: 1$.

test diets were fed to fish at 17:00 on the same day. The non-fecal nitrogen excretion through the gills and in the urine was measured according to the procedures reported elsewhere ${ }^{4)}$ after the termination of feeding experiments. Briefly, after feeding the final meal at 11:30 on the 14th day (Expts. I and III) or the 19th day (Expt. II), the fish of each test group were transferred promptly to the tanks of the non-fecal nitrogen collection system at 12:00 and kept precisely for $24 \mathrm{~h}$ without feeding to measure non-fecal nitrogen excretion. The fish were weighed after the measurement of nitrogen excretion, and this fish body weight and total amount of diet accepted by fish during 24 hours before the measurement were used for the calculation of non-fecal nitrogen excretion rate. The procedure of fecal collection and the feeding schedule were the same as those in a previous experiment with rainbow trout. ${ }^{7)}$

The culture conditions of each experiment are indicated in Table 3, and the highest feeding level was equal to satia-
Table 3. Culture conditions in the three experiments

\begin{tabular}{lrcccccc}
\hline & $\begin{array}{c}\text { No. Initial } \\
\text { of } \\
\text { fish }\end{array}$ & $\begin{array}{c}\text { Feeding wt. } \\
\text { (g) }\end{array}$ & $\begin{array}{c}\text { Fate } \\
(\%)\end{array}$ & $\begin{array}{c}\text { Feeding } \\
\text { level }\end{array}$ & $\begin{array}{c}\text { Expt. } \\
\text { period } \\
\text { (days) }\end{array}$ & $\begin{array}{c}\text { Water } \\
\left({ }^{\circ} \mathrm{C}\right)\end{array}$ & protein \\
\hline Expt. I & 4 & 243.2 & $0-2.0$ & 7 & 14 & $\begin{array}{c}25-27 \\
(26)\end{array}$ & Casein \\
Expt. II & 25 & 5.6 & $0-3.8$ & 7 & 19 & $\begin{array}{c}22-24 \\
(23)\end{array}$ & Casein \\
Expt. III & 30 & 3.9 & $0-5.2$ & 7 & 14 & $\begin{array}{c}22-24 \\
(23)\end{array}$ & Fish meal \\
\hline
\end{tabular}

* Average values in parentheses.

tion. In Expt. I four fish having a mean weight of $243.2 \mathrm{~g}$ and in Expt. II 25 fish weighing $5.6 \mathrm{~g}$ each were fed casein diets, and in Expt. III 30 fish weighing $3.9 \mathrm{~g}$ each were fed fish meal diets at seven different rates ranging from 0 to $5.2 \%$ of body weight per day at $22-27^{\circ} \mathrm{C}$.

The whole body samples were homogenized thoroughly by a Multi-blender Mill (Nihonseiki Kaisha Ltd.) for analysis. In the case of the bigger fish in Expt. I, they were subsequently mixed in a small mixer and homogenized again by a Mycolloider (Tokushu Kika Kogyo Co., Ltd.).

Calculations of DE, ME, heat increment $(\mathrm{HI})$, and net energy (NE) values were carried out according to the methods described previously. ${ }^{\text {) }}$

\section{Results and Discussion}

\section{Energy Requirements for Maintenance of Body Weight and Activity, and for Maximum Growth}

The results of feeding and digestibility of energy, protein and lipid determined in Expts. I-III are shown in Table 4 . The feeding rates which provided positive percent gain and feed efficiency were $0.71,0.62$, and $1.51 \%$ of body weight per day in Expts. I, II, and III, respectively. The satiation level in Expt. III was higher than that in Expt. II in spite of similar water temperature and fish size. There were no marked differences in the digestibility of energy, protein, and lipid corresponding to feeding rates in Expts. I-III. However, the digestibility values were lower in the practical diet containing fish meal, defatted soybean meal, and yellow grease in Expt. III, compared to those of the casein diet in Expts. I and II, indicating that it was affected by the dietary ingredients.

The relationship between the DE intake and the percent gain in Expts. I-III is given in Figs. 1 and 2. In the fish fed at low feeding levels, the digestibilities determined at restricted levels were used for calculation of DE. The energy value intersecting the horizontal axis was equivalent to the DE requirement for maintenance of body weight and activity, and the value near the inflection point or at a satiable feeding level was close to the DE requirement for maximum growth. The values thus estimated are shown in Table 5. The DE requirements for maintenance of body weight and activity determined in Expts. I, II, and III were $21.6,18.4$, and $35.4 \mathrm{kcal} / \mathrm{kg}$ body weight per day $(25.9$, 23.1 , and $49.0 \mathrm{kcal} / \mathrm{kg}$ body weight per day in GE), and the corresponding feeding rates were $0.58,0.51$, and $1.04 \%$ of body weight per day, respectively, being significantly affected by the diets. These values obtained in Expts. I and II were nearly equal to those of rainbow trout 
Table 4. Results of the three feeding experiments on carp*

\begin{tabular}{|c|c|c|c|c|c|c|c|c|c|c|}
\hline & \multirow{2}{*}{$\begin{array}{c}\text { Feeding } \\
\text { rate } \\
(\%)\end{array}$} & \multirow{2}{*}{$\begin{array}{l}\text { No. } \\
\text { of } \\
\text { fish }\end{array}$} & \multicolumn{2}{|c|}{$\begin{array}{c}\text { Total body wt. } \\
(\mathrm{g})\end{array}$} & \multirow{2}{*}{$\begin{array}{l}\text { Percent } \\
\text { gain }\end{array}$} & \multirow{2}{*}{$\begin{array}{c}\text { Diet } \\
\text { consumed } \\
\text { (g) }\end{array}$} & \multirow{2}{*}{$\begin{array}{c}\text { Feed } \\
\text { efficiency }\end{array}$} & \multicolumn{3}{|c|}{ Apparent digestibility (\%) } \\
\hline & & & Initial & Final & & & & Energy & $\begin{array}{l}\text { Crude } \\
\text { protein }\end{array}$ & $\begin{array}{l}\text { Crude } \\
\text { lipid }\end{array}$ \\
\hline Expt. I & 0 & 4 & 984.8 & 894.1 & -9.2 & 0 & - & - & - & - \\
\hline \multirow[t]{6}{*}{ (14 days) } & 0.31 & 4 & 981.5 & 951.5 & -3.1 & 40.65 & -0.74 & - & - & - \\
\hline & 0.51 & 4 & 939.7 & 927.3 & -1.3 & 66.73 & -0.19 & & & \\
\hline & 0.71 & 4 & 994.6 & 1006.3 & 1.2 & 99.48 & 0.12 & - & - & - \\
\hline & 0.99 & 4 & 958.1 & 1016.9 & 6.1 & 137.41 & 0.43 & - & - & - \\
\hline & 1.46 & 4 & 985.2 & 1117.8 & 13.5 & 214.28 & 0.62 & 83.3 & 94.6 & 88.8 \\
\hline & 1.96 & 4 & 965.2 & 1148.8 & 19.0 & 284.45 & 0.64 & 82.8 & 95.8 & 89.5 \\
\hline Expt. II & 0 & 25 & 141.5 & 122.7 & -13.3 & 0 & - & - & - & - \\
\hline \multirow[t]{6}{*}{ (19 days) } & 0.31 & 25 & 141.9 & 135.7 & -4.4 & 8.17 & -0.76 & - & - & - \\
\hline & 0.62 & 25 & 140.4 & 141.9 & 1.1 & 16.64 & 0.09 & - & - & - \\
\hline & 1.01 & 25 & 137.8 & 154.2 & 11.9 & 28.02 & 0.59 & - & - & - \\
\hline & 1.94 & 25 & 141.5 & 192.2 & 35.8 & 61.55 & 0.82 & - & - & - \\
\hline & 2.80 & 25 & 139.9 & 266.6 & 61.9 & 97.44 & 0.89 & 79.7 & 96.0 & 95,0 \\
\hline & 3.80 & 25 & 142.0 & 259.0 & 82.4 & 144.85 & 0.81 & 79.5 & 94.3 & 87.0 \\
\hline Expt. III & 0 & 30 & 117.4 & 94.3 & -19.7 & 0 & - & - & - & - \\
\hline \multirow{6}{*}{ (14 days) } & 0.32 & 30 & 116.8 & 97.5 & -17.0 & 4.83 & -3.99 & - & - & - \\
\hline & 0.64 & 30 & 117.0 & 103.0 & -0.1 & 9.80 & -1.43 & - & - & - \\
\hline & 1.51 & 30 & 114.4 & 124.6 & 8.9 & 25.20 & 0.40 & - & - & - \\
\hline & 2.58 & 30 & 115.4 & 147.2 & 27.5 & 47.40 & 0.67 & - & - & - \\
\hline & 3.79 & 30 & 115.2 & 173.8 & 50.9 & 76.73 & 0.76 & 72.2 & 82.7 & 74,6 \\
\hline & 5.17 & 30 & 116.4 & 211.5 & 81.7 & 118.72 & 0.80 & 70.1 & 83.9 & 70.6 \\
\hline
\end{tabular}

* Water temperature was $25-27^{\circ} \mathrm{C}$ in Expt. I and $22-24^{\circ} \mathrm{C}$ in Expts. II and III.

fed a casein diet in an earlier experiment. ${ }^{7}$ The DE requirements for maximum growth determined in Expts. I, II,

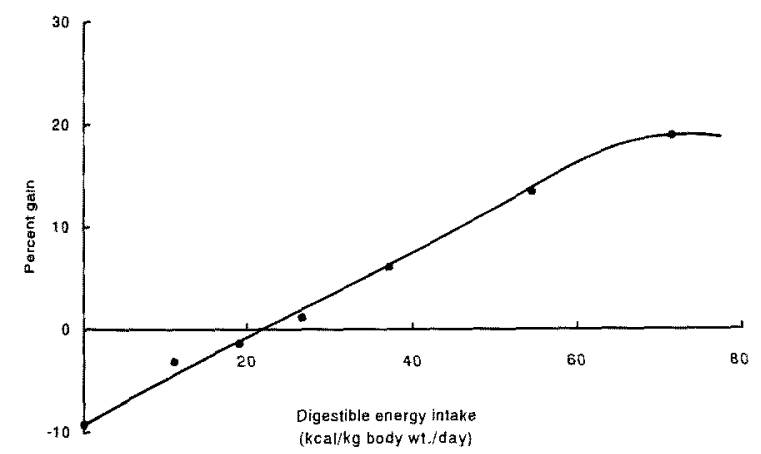

Fig. 1. Relationship between digestible energy intake and percent gain in carp fed the casein diet (Expt. I).

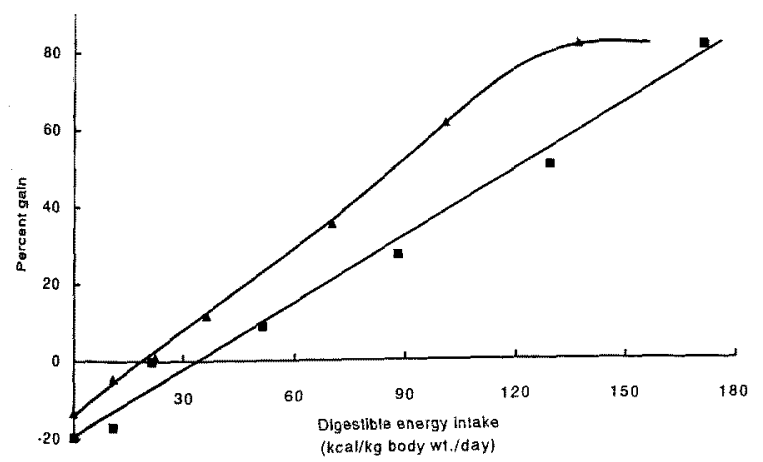

Fig. 2. Relationship between digestible energy intake and percent gain in carp fed the experimental diets ( $\triangle$, Expt. II; $-\longrightarrow$, Expt. III). and III were 68,130 , and $172 \mathrm{kcal} / \mathrm{kg}$ body weight per day $(82,164$, and $245 \mathrm{kcal} / \mathrm{kg}$ body weight per day in GE), being influenced by diet as well as fish size. Figure 3 indicates the relationship between the DE intake and the feed efficiency. The DE requirements for maintenance of body weight and activity determined based upon feed efficiency in Expts. I-III were 23.1, 19.3, and $31.0 \mathrm{kcal} / \mathrm{kg}$ body weight/day, being approximately equal to those obtained based upon percent gain. The DE values required to ob-

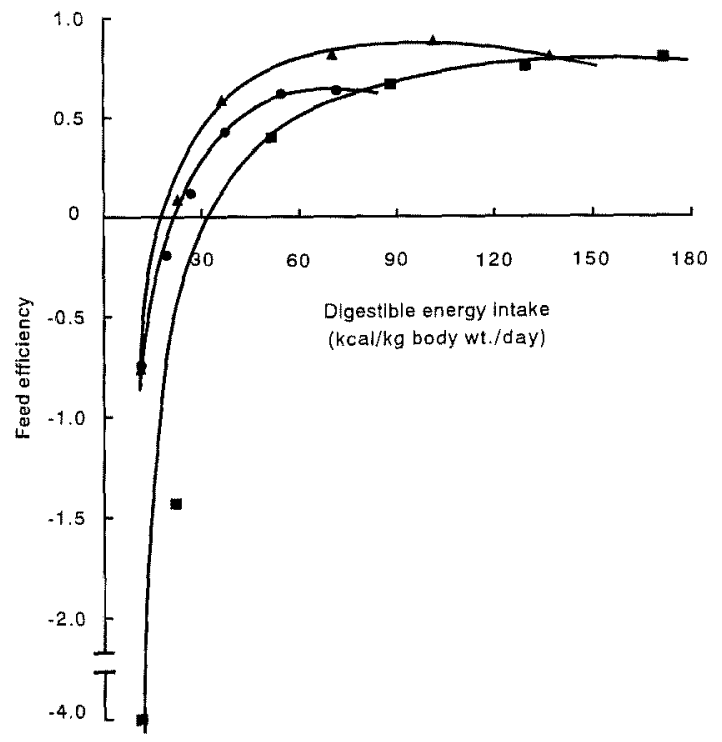

Fig. 3. Relationship between digestible energy intake and feed efficiency in carp fed the casein diet $(\bullet$, Expt. I; $\hookrightarrow$, Expt. II) or the fish meal diet $(\bullet$, Expt. III). 


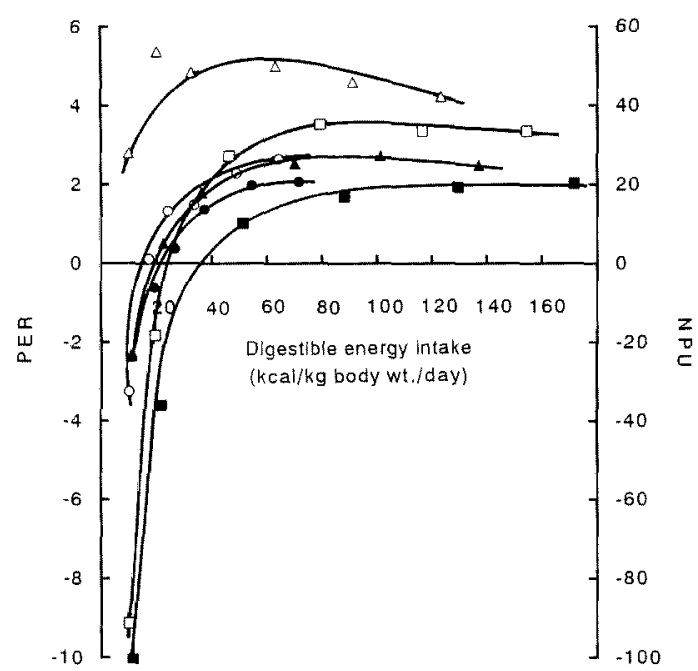

Fig. 4. Relationship between digestible energy intake and PER or NPU in carp fed the casein diet (Expts. I and II) or the fish meal diet (Expt. III).

Expt. I: $\bullet \bullet$, PER; $\bigcirc$, NPU.

Expt. II: $\hookrightarrow$, PER; $\leftrightarrow$, NPU.

Expt. III: - $\square$ PER; $\square \square$, NPU.

tain maximum feed efficiency were 55,100 , and $160 \mathrm{kcal} /$ $\mathrm{kg}$ body weight/day in Expts. I to III, respectively, being lower than those for the maximum growth.

The relationship between the DE intake and the PER or NPU in Expts. I-III is shown in Fig. 4. Sufficient DE should be added to a diet in order for the dietary protein to be utilized efficiently within the animal body. ${ }^{9}$ Therefore, in fish receiving low levels of diets, tissue proteins were utilized to yield energy through amino acid degradation to counterbalance the energy requirement, ${ }^{10)}$ resulting in negative nitrogen balance and decrease of PER and NPU as shown in Fig. 4. Both PER and NPU increased with increase of feed intake, reaching a plateau at a level of 50$80 \mathrm{kcal} / \mathrm{kg}$ body weight $/$ day DE intake. In Expts. I and II the $D E$ requirements for maintenance of body protein level, namely the values at the zero point for PER or NPU, were about $20 \mathrm{kcal} / \mathrm{kg}$ body weight $/$ day regardless of fish size. The energy values for a maximum PER or NPU were $60-70 \mathrm{kcal} / \mathrm{kg}$ body weight/day and agreed well with the preceding observation in rainbow trout fed a casein diet. ${ }^{7}$ In Expt. III the requirement for maintenance of body protein content slightly increased to about $25-35 \mathrm{kcal} / \mathrm{kg}$ body weight/day, and that for maximum PER or NPU rose to $80-90 \mathrm{kcal} / \mathrm{kg}$ body weight $/$ day, both the values being considerably influenced by the dietary protein source.

Energy Requirement for Maintenance of Fish Body Energy Content, Net Energy Value for Maintenance and Activity, and Heat Increment

The proximate composition of whole body of fish in Expts. II and III and the relationship between the DE intake and the lipid retention in fish body are shown in Table 6 and Fig. 5. The DE requirements for maintenance of fish body lipid content were 44 and $71 \mathrm{kcal} / \mathrm{kg}$ body weight/ day in Expts. II and III, respectively, and the maximum lipid retention was $240 \mathrm{mg} / 100 \mathrm{~g}$ body weight/day in both

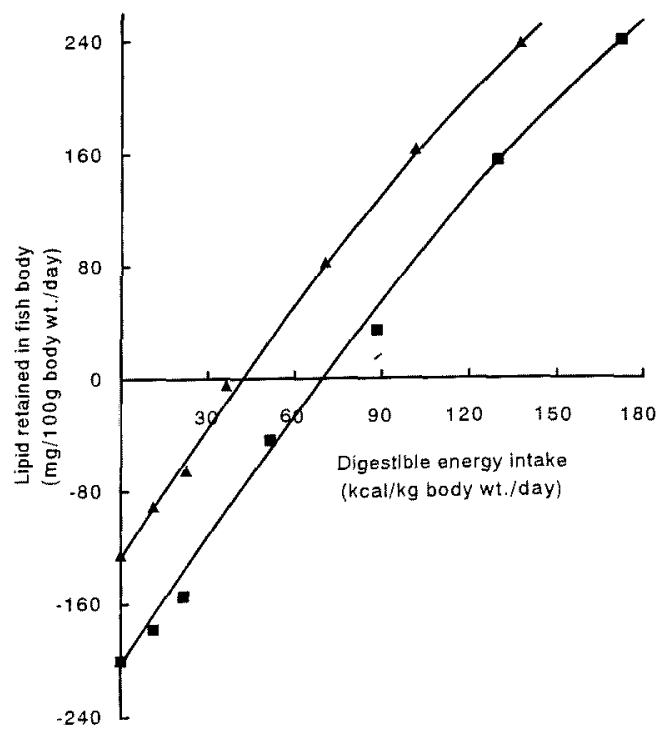

Fig. 5. Relationship between digestible energy intake and lipid retention in carp fed the casein diet ( $\neg \Lambda$, Expt. II) or the fish meal diet (๒, Expt. III).

Table 5. Energy requirements for maintenance of body weight and activity, and a maximum growth determined based upon percent gain and energy balance in carp fed on the casein diet (Expts. I and II) or the fish meal diet (Expt. III)

\begin{tabular}{lccc}
\hline \multicolumn{1}{c}{ Energy requirement } & Expt. I & Expt. II & Expt. III \\
\hline $\begin{array}{l}\text { Maintenance of body } \\
\text { weight and activity: }\end{array}$ & & & \\
$\quad$ DE (kcal/kg body wt./day) & 21.6 & 18.4 & 35.4 \\
$\quad$ Feeding rate (\%) & 0.58 & 0.51 & 1.04 \\
Maximum growth: & & & \\
$\quad$ DE (kcal/kg body wt./day) & 68 & 130 & 172 \\
$\quad$ Feeding rate (\%) & 1.83 & 3.60 & 5.17 \\
$\begin{array}{l}\text { Maintenance of energy } \\
\text { content of fish body: }\end{array}$ & & & \\
$\quad \begin{array}{l}\text { DE (kcal/kg body wt./day) } \\
\text { Feeding rate (\%) }\end{array}$ & 24.2 & 41.4 & 49.0 \\
$\begin{array}{l}\text { Decrease of energy content } \\
\text { during starvation }=\text { NEm }\end{array}$ & 0.65 & 1.15 & 1.43 \\
(kcal/kg body wt./day) & 12.7 & 22.4 & 30.9 \\
\hline
\end{tabular}

* NEm, maintenance energy.

the experiments. Even in the fish receiving sufficient amounts of energy to satisfy the requirement for maintenance of body weight and activity, the body lipid content decreased with increase of the moisture content in the same way as for rainbow trout in the previous experiment. ${ }^{7}$ Therefore, Fig. 6 was prepared by plotting the energy retention in fish body on the vertical axis and the ME intake on the horizontal axis using the data obtained in Expts. I-III. The energy value intersecting the horizontal axis where the energy balance of fish body is zero, is equal to the ME requirement for maintenance of energy content of fish body. Furthermore, the energy cost at the zero point on the vertical axis, the decrease in energy content of fish body during starvation, is considered to be approximately equal to the net energy value for maintenance of body energy and activity (NEm). ${ }^{1)}$ 
Table 6. Proximate composition of carp fed on the experimental diets

\begin{tabular}{|c|c|c|c|c|c|c|}
\hline & $\begin{array}{c}\text { Feeding } \\
\text { rate } \\
(\%)\end{array}$ & $\begin{array}{c}\text { Moisture } \\
(\%)\end{array}$ & $\begin{array}{c}\text { Crude } \\
\text { protein } \\
(\%)\end{array}$ & $\begin{array}{c}\text { Crude } \\
\text { lipid } \\
(\%)\end{array}$ & $\begin{array}{c}\text { Crude } \\
\text { ash } \\
(\%)\end{array}$ & $\begin{array}{c}\text { Gross } \\
\text { energy } \\
\text { (kcal/g) }\end{array}$ \\
\hline \multirow[t]{8}{*}{ Expt. I } & Initial & 75.0 & 16.8 & 5.2 & 3.4 & 1.41 \\
\hline & 0 & 75.1 & 16.4 & 5.1 & 3.7 & 1.37 \\
\hline & 0.30 & 76.7 & 15.7 & 4.1 & 3.4 & 1.36 \\
\hline & 0.51 & 76.3 & 15.8 & 4.3 & 3.7 & 1.40 \\
\hline & 0.71 & 75.3 & 15.8 & 5.4 & 3.4 & 1.40 \\
\hline & 0.99 & 77.3 & 15.3 & 4.4 & 2.7 & 1.43 \\
\hline & 1.46 & 75.3 & 15.0 & 6.3 & 2.6 & 1.45 \\
\hline & 1.96 & 74.7 & 15.0 & 6.7 & 2.7 & 1.50 \\
\hline \multirow[t]{8}{*}{ Expt. II } & Initial & 79.4 & 13.7 & 4.1 & 2.8 & 1.19 \\
\hline & 0 & 82.4 & 12.9 & 2.1 & 2.9 & 0.91 \\
\hline & 0.31 & 81.9 & 13.2 & 2.5 & 3.1 & 0.90 \\
\hline & 0.62 & 81.0 & 13.9 & 2.8 & 3.0 & 0.99 \\
\hline & 1.01 & 80.5 & 13.5 & 3.5 & 3.4 & 1.03 \\
\hline & 1.94 & 79.0 & 13.9 & 4.3 & 2.9 & 1.19 \\
\hline & 2.80 & 78.5 & 13.5 & 5.0 & 2.9 & 1.19 \\
\hline & 3.80 & 77.7 & 13.9 & 5.7 & 2.8 & 1.31 \\
\hline \multirow[t]{8}{*}{ Expt. III } & Initial & 77.8 & 14.5 & 5.7 & 2.4 & 1.23 \\
\hline & 0 & 79.8 & 13.9 & 3.9 & 3.0 & 1.04 \\
\hline & 0.32 & 79.0 & 14.3 & 4.1 & 2.8 & 1.09 \\
\hline & 0.64 & 79.4 & 14.5 & 4.1 & 2.6 & 1.10 \\
\hline & 1.51 & 79.3 & 14.3 & 4.6 & 2.5 & 1.15 \\
\hline & 2.58 & 78.1 & 14.8 & 4.9 & 2.3 & 1.25 \\
\hline & 3.79 & 77.6 & 14.5 & 5.6 & 2.4 & 1.30 \\
\hline & 5.17 & 77.7 & 14.5 & 5.7 & 2.4 & 1.32 \\
\hline
\end{tabular}

The DE value required for maintenance of fish body energy content is shown in Table 5 together with the NEm value. In Expts. I, II, and III, the respective DE values for maintenance of energy content of fish body were 24.2, 41.4 , and $49.0 \mathrm{kcal} / \mathrm{kg}$ body weight $/$ day $(29.1,52.0$, and $67.9 \mathrm{kcal} / \mathrm{kg}$ body weight/day in GE), and the corresponding feeding rates were $0.65,1.15$, and $1.43 \%$ of body weight/day, affected by both diet and fish size. The NEm values were $12.7,22.4$, and $30.9 \mathrm{kcal} / \mathrm{kg}$ body weight $/$ day and increased with decrease of fish size, as is usually observed in fish and mammals. As already discussed in the preceding paper, ${ }^{7}$ the difference between the $\mathrm{ME}$ value for maintenance of body energy content and the NEm value is approximately equal to the $\mathrm{HI}$ of feeding $(\mathrm{HI}=$ $\mathrm{ME}-\mathrm{NEm}$, productive energy $(\mathrm{NEp})=0$ ). As shown in Table 7, the ME requirements for maintenance of energy content of fish body were $23.7,40.3$, and $47.1 \mathrm{kcal} / \mathrm{kg}$ body weight/day in fish from Expts. I to III, and the proportion of NEm/ME was $53.5,55.7$, and $65.5 \%$, which increased with decrease of fish size. The HI of feeding calculated from these values were $11.0,17.9$, and $16.2 \mathrm{kcal} / \mathrm{kg}$ body weight/day, and the HI/ME rates were 46.5, 44.3, and $34.5 \%$, influenced by fish size.

\section{Dietary Energy Budgets}

Dietary energy budgets at each feeding rate were determined as reported previously. ${ }^{7)}$ In brief, the amount of energy retained in fish body, calculated by proximate analysis, is equal to the productive energy (NEp) value, a part of the NE value, and $\mathrm{HI}$ is calculated by the following equation:
Table 7. The requirement of ME for the maintenance of energy balance and its ratio to $\mathrm{HI}$ and NEm in carp fed on the casein diet (Expts. I and II) or the fish meal diet (Expt. III)

\begin{tabular}{lccc}
\hline & Expt. I & Expt. II & Expt. III \\
\hline ME & 23.7 & 40.3 & 47.1 \\
(kcal/kg body wt./day) & & 17.9 & 16.2 \\
HI & 11.0 & & \\
(kcal/kg body wt./day) & & 44.3 & 34.5 \\
HI/ME (\%) & 46.5 & 22.4 & 30.9 \\
NEm & 12.7 & & \\
(kcal/kg body wt./day) & 53.5 & 55.7 & 65.5 \\
NEm/ME (\%) & & \\
\hline
\end{tabular}

Abbreviations: $M E$, metabolizable energy; $\mathrm{HI}$, heat increment; NEm, maintenance energy.

$$
\begin{aligned}
\mathrm{HI} & =(\mathrm{ME}-\mathrm{NEm})-\mathrm{NEp} \\
& =\mathrm{ME}-\mathrm{NE}(\mathrm{NEm}+\mathrm{NEp})
\end{aligned}
$$

The HI, NE, NEm, and NEp values obtained by this method and the percentage of measured fecal energy (FE) value and non-fecal energy in the GE or ME values are shown in Table 8. The ratio of $\mathrm{HI}$ or NE remained almost constant independent of the GE or ME intake in all the experiments, although the increase of GE was linked to the decrease of NEm value and the increase of NEp value. The amount of energy supply which results in negative energy retention, thus giving an NEp value of zero, can not satisfy the NEm requirement. Therefore, the dietary energy budgets for the fish which showed a positive energy retention (NEp) are illustrated in Fig. 7. The energy budgets in fish fed diets at the level required for maximum growth are also shown in Fig. 8. The energy partitionings of the experimental diets, at the GE intake $(100 \%)$ level required for maximum growth were as follows: FE: $16.7-29.9 \%$, non-fecal energy: $1.5-2.0 \%$, HI: $31.9-38.9 \%$, and NE: 36.7-43.2\% (NEm: 12.6-15.5\%, NEp: $24.1-27.7$ ), respectively. Thus the proportions of FE values were relatively

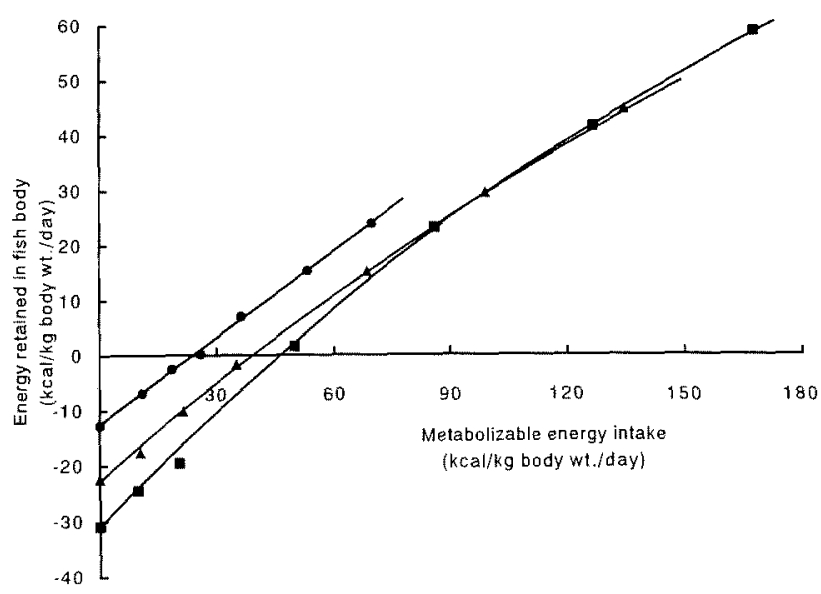

Fig. 6. Relationship between metabolizable energy intake and energy retention in carp fed the cascin diet ( $\bullet$, Expt. I; $\wedge \mathbf{A}$, Expt. II) or the fish meal diet ( $\square$, Expt. III).

The amount of endogenous nitrogen excretion was calculated as $8.6 \mathrm{mg}$ (Expt. I) and $15.7 \mathrm{mg}$ (Expts. II and $\mathrm{III}) / 100 \mathrm{~g}$ body wt. / day. 
Table 8. Energy budgets in carp fed on the casein diet (Expts. I and II) or the fish meal diet (Expt. III)

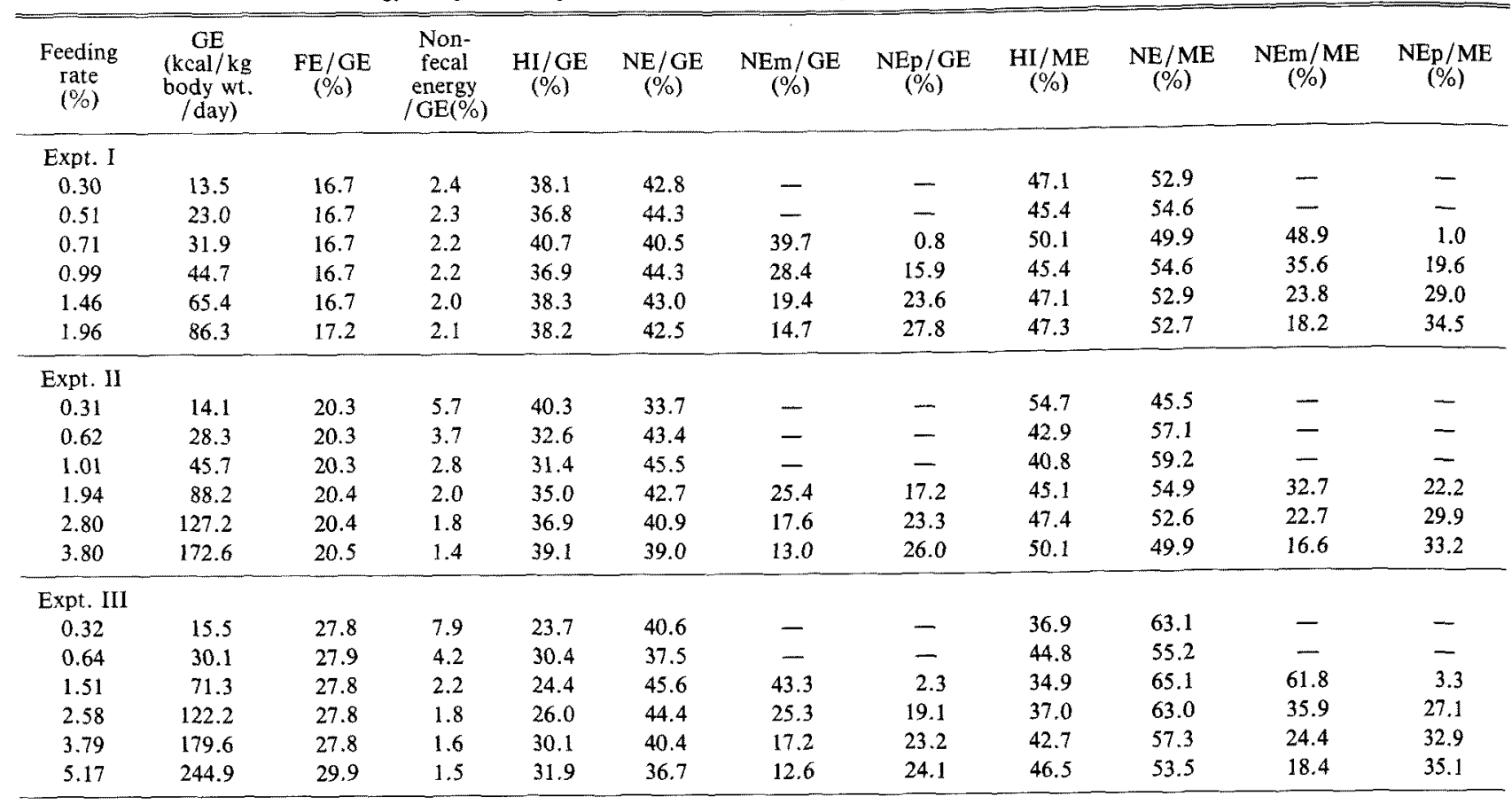

Abbreviations: GE, gross energy; FE, fecal energy; HI, heat increment; NE, net energy; NEm, maintenance energy; NEp, productive energy; ME, metabolizable energy.

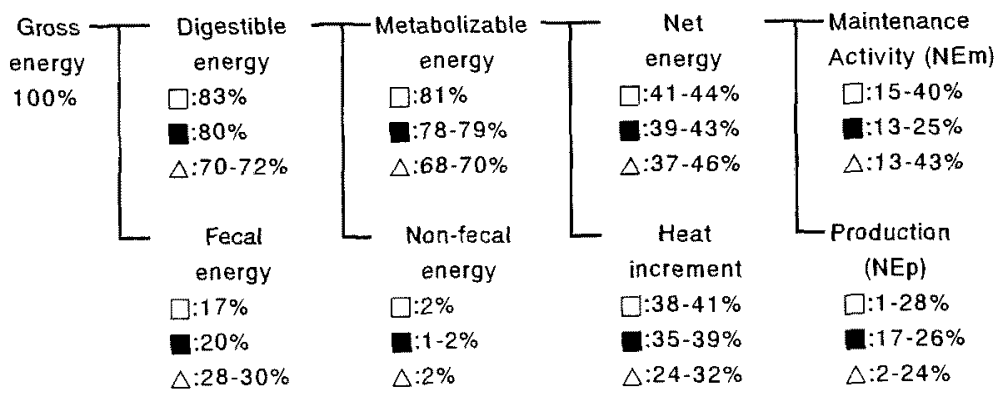

Fig. 7. Energy balance pattern in carp fed the casein diet ( $\square$, Expt. I and $\square$, Expt. II) or the fish meal diet ( $\triangle$, Expt. III).

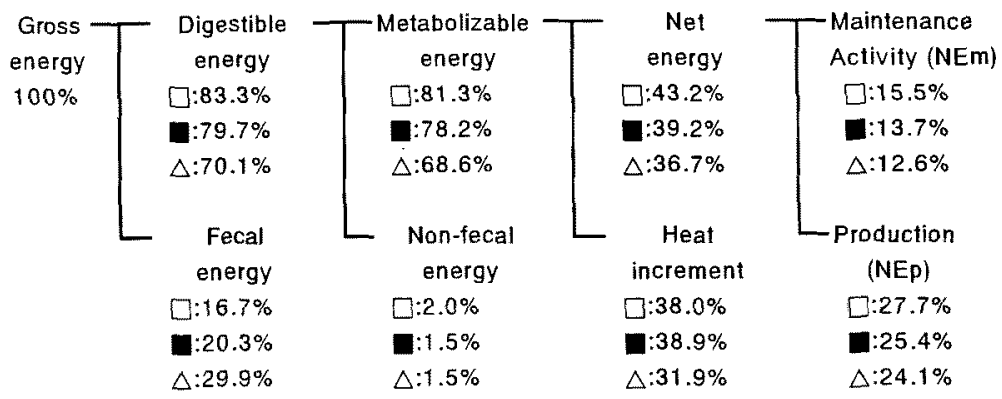

Fig. 8. Energy balance pattern at the level required for maximum growth in carp fed the casein diet ( $\square$, Expt. I and $\square$, Expt. II) or the fish meal diet $(\triangle$, Expt. III).

high and were greatly influenced by the quality of diets as already demonstrated in rainbow trout in the preceding study, ${ }^{7}$ and the HI of feeding was found to occupy a large portion (30-40\%) of the energy budget in fish. The NEm value of carp was about twice the value obtained with rainbow trout. ${ }^{7}$ 
Table 9. Non-fecal energy loss and metabolizable energy contents in carp fed on the casein diet (Expts. I and II) or the fish meal diet (Expt. III)

\begin{tabular}{|c|c|c|c|c|c|c|c|}
\hline $\begin{array}{l}\text { Total } \\
\text { body } \\
\text { weight } \\
\text { (g) }\end{array}$ & $\begin{array}{l}\text { Feeding } \\
\text { rate } \\
(\%)\end{array}$ & $\begin{array}{c}\text { Non-fecal } \\
\text { energy } \\
\text { (kcal/kg } \\
\text { body wt. } \\
\text { /day) }\end{array}$ & $\begin{array}{c}\text { Non-fecal } \\
N / \\
N \text { intake } \\
(\%)\end{array}$ & $\begin{array}{c}\text { Non-fecal } \\
\text { energy } \\
\text { /DE (\%) }\end{array}$ & $\begin{array}{c}\mathrm{ME} \\
\text { (kcal/g } / \mathrm{g}\end{array}$ & $\begin{array}{c}\mathrm{ME} / \mathrm{GE} \\
(\%)\end{array}$ & $\begin{array}{c}\mathrm{ME} / \mathrm{DE} \\
(\%)\end{array}$ \\
\hline \multicolumn{8}{|l|}{ Expt. I } \\
\hline 894.1 & 0 & $0.68^{* 1}$ & - & - & - & - & - \\
\hline 951.5 & 0.30 & 0.29 & 32.6 & 2.6 & 3.65 & 81.2 & 97.4 \\
\hline 1006.3 & 0.71 & 0.65 & 30.9 & 2.4 & 3.65 & 81.3 & 97.6 \\
\hline 1016.9 & 0.98 & 0.93 & 31.9 & 2.5 & 3.65 & 81.2 & 97.5 \\
\hline 1117.8 & 1.41 & 1.23 & 29.5 & 2.3 & 3.66 & 81.4 & 97.7 \\
\hline 1148.8 & 1.91 & 1.74 & 30.7 & 2.5 & 3.63 & 80.8 & 97.6 \\
\hline \multicolumn{8}{|l|}{ Expt. II } \\
\hline 122.7 & 0 & $1.56^{* 2}$ & - & - & - & - & - \\
\hline 135.7 & 0.32 & 0.82 & 83.4 & 7.1 & 3.36 & 74.0 & 92.9 \\
\hline 154.2 & 1.08 & 1.34 & 41.7 & 3.6 & 3.49 & 76.8 & 96.4 \\
\hline 192.2 & 1.96 & 1.74 & 28.7 & 2.5 & 3.53 & 77.7 & 97.5 \\
\hline 226.6 & 2.81 & 2.28 & 26.2 & 2.2 & 3.54 & 77.9 & 97.8 \\
\hline 259.0 & 4.51 & 2.88 & 20.6 & 1.8 & 3.55 & 78.1 & 98.2 \\
\hline \multicolumn{8}{|l|}{ Expt. III } \\
\hline 94.3 & 0 & $2.05^{* 2}$ & - & - & - & - & - \\
\hline 97.5 & 0.35 & 1.30 & 98.9 & 10.9 & 3.04 & 64.3 & 89.1 \\
\hline 103.0 & 0.68 & 1.36 & 53.0 & 5.9 & 3.22 & 67.9 & 94.1 \\
\hline 124.6 & 1.51 & 1.54 & 27.0 & 3.0 & 3.31 & 70.0 & 97.0 \\
\hline 147.2 & 2.48 & 2.07 & 22.2 & 2.5 & 3.33 & 70.4 & 97.5 \\
\hline 173.8 & 3.52 & 2.66 & 20.0 & 2.2 & 3.34 & 70.6 & 97.8 \\
\hline 211.5 & 4.89 & 3.48 & 18.9 & 2.1 & 3.25 & 68.6 & 97.9 \\
\hline
\end{tabular}

${ }^{*}$ The amount of endogenous nitrogen excretion was calculated as $8.6 \mathrm{mg} / 100 \mathrm{~g}$ body weight / day at $\left.27^{\circ} \mathrm{C} .{ }^{6}\right)$

${ }^{*}$ The amount of endogenous nitrogen excretion was calculated as $15.7 \mathrm{mg} / 100 \mathrm{~g}$ body weight $/$ day at $23^{\circ} \mathrm{C} .{ }^{4}$ )

Brett and Groves $^{2)}$ estimated energy budgets based on various results obtained in 30 experiments with carnivorous fish by various researchers. Ratios to GE intake were $20 \%$ for $\mathrm{FE}, 7 \%$ for non-fecal energy, $14 \%$ for $\mathrm{HI}$, and $59 \%$ for NE (NEm: $5-59 \%, 30 \%$ on average and NEp: $0-45 \%, 29 \%$ on average). The proportion of non-fecal energy losses and NEm to GE was higher and that of $\mathrm{HI}$ was lower than those in the present experiment. Cho ${ }^{11}$ also calculated the energy budgets in rainbow trout by an indirect measurement of DE value, determining oxygen consumption during feeding or fasting period, and assuming that energy lost through the gills and in the urine accounts for $8 \%$ of the total energy intake. When a diet prepared using fish meal and soybean meal and having 36\% digestible protein and $11 \%$ lipid was fed to rainbow trout of $19-66 \mathrm{~g}$ at $15^{\circ} \mathrm{C}$, the energy distribution of GE intake was $26 \%$ for $\mathrm{FE}, 8 \%$ for non-fecal energy, $8 \%$ for $\mathrm{HI}$, and $58 \%$ for NE (NEm: $17 \%$ and NEp: $41 \%$ ). The ratios of non-fecal energy losses, NEp, and NEm were higher and the percentage of $\mathrm{HI}$ was lower than those of the present experiment.

Many studies have been conducted to determine $\mathrm{HI}$ of feeding in fish by direct calorimetry or indirect calorimetry measuring oxygen consumption. In the case of measuring HI of feeding by indirect calorimetry in largemouth bass $^{12,13)}$ and bluegill sunfish, ${ }^{14,15)}$ the proportion of $\mathrm{HI} / \mathrm{GE}$ was $11.3-14.9 \%$. Smith et al ${ }^{16}$ measured $\mathrm{HI}$ of feeding by direct calorimetry in rainbow trout by feeding them a purified diet and reported it as $1.6 \%$ of the ingested ME.
Cho ${ }^{11)}$ observed that the value of energy retention measured by indirect calorimetry was $8-10 \%$ higher than that obtained by carcass analysis. The $\mathrm{HI}$ of feeding determined in our experiment was higher than the values reported hitherto. This might have resulted from overestimation due to the inclusion of all the energy requirements for digestion and absorption processes, transformation and in-

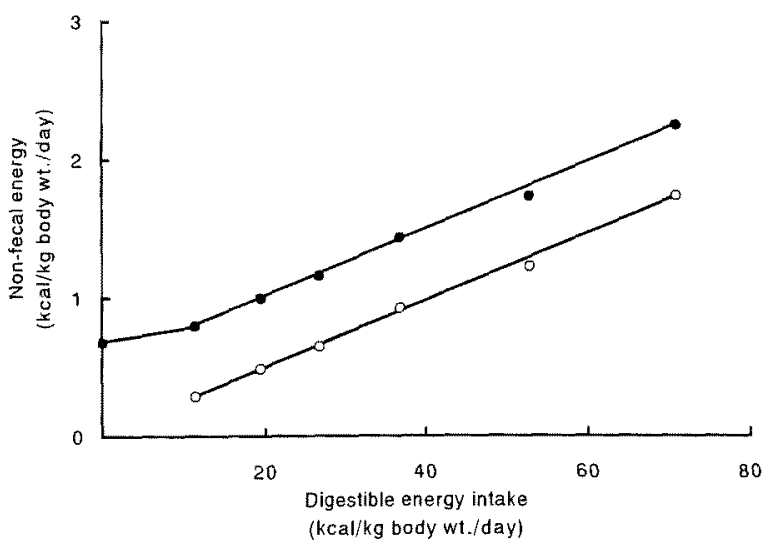

Fig. 9. Relationship between digestible energy intake and non-fecal energy loss in carp fed the casein diet (Expt. I).

The amount of endogenous nitrogen excretion was calculated as $8.6 \mathrm{mg} / 100 \mathrm{~g}$ body wt./ day. ${ }^{6}$

$\bullet$, total non-fecal energy; $\multimap-0$, total non-fecal energy-endogenous nitrogen excretion. 


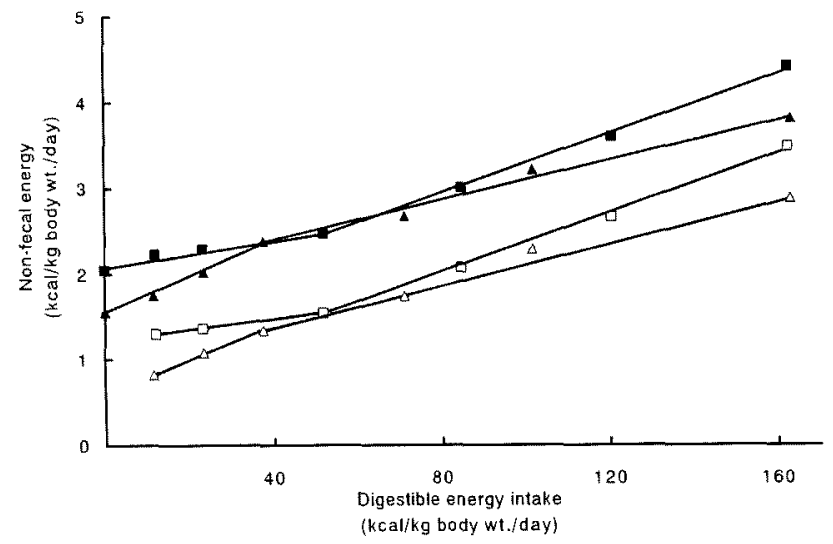

Fig. 10. Relationship between digestible energy intake and non-fecal energy loss in carp fed the experimental diets (Expts. II and III).

The amount of endogenous nitrogen excretion was calculated as $15.7 \mathrm{mg} / 100 \mathrm{~g}$ body wt./ day. ${ }^{4)}$

Expt. II: $\Delta$, total non-fecal energy; $\Delta \Delta$, total non-fecal energy-endogenous nitrogen excretion.

Expt. III: $\square$, total non-fecal energy; $\square-\square$, total non-fecal energy-endogenous nitrogen excretion.

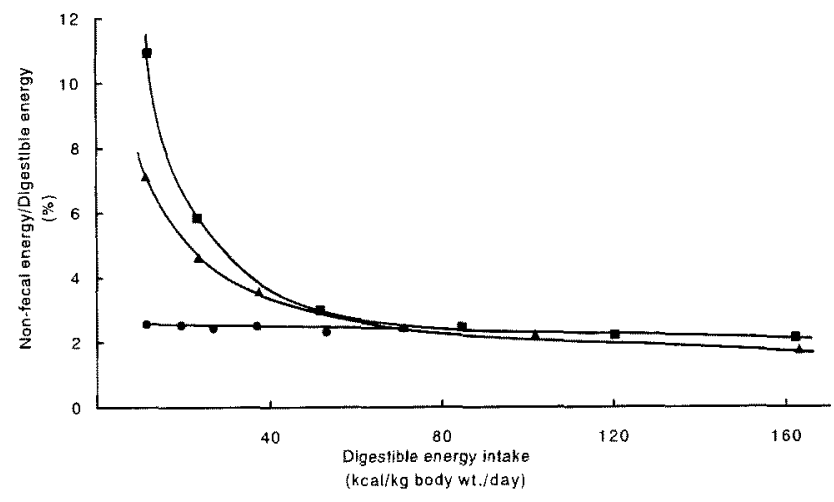

Fig. 11. Effect of digestible energy intake on non-fecal energy loss in carp fed the casein diet $(\bullet-$ Expt. I; $\wedge$, Expt. II) or the fish meal diet $(\square$, Expt. III).

The amount of endogenous nitrogen excretion was calculated as $8.6 \mathrm{mg}$ (Expt. I) and $15.7 \mathrm{mg}$ (Expts. II and III) $/ 100 \mathrm{~g}$ body wt./day.

terconversion of the substrates and their retention in tissues and formation and excretion of metabolic wastes.

\section{Non-fecal Energy Loss}

The non-fecal energy losses through the gills and in the urine measured at $27^{\circ} \mathrm{C}$ in Expt. I and at $23^{\circ} \mathrm{C}$ in Expts. II and III together with the ME contents of diets are shown in Table 9. The ME/DE rate in the fish fed to satiation was not much different among the treatments and ranged from 97.6 to $98.2 \%$ in the experimental groups. The proportion of non-fecal energy/DE in the fish fed to satiation was $2.5 \%$ and $1.8 \%$ in Expts. I and II, respectively, the ratios tending to rise in large-size carp as mentioned previously. ${ }^{5)}$ Figures 9 and 10 indicate the relationship between the DE intake and the non-fecal energy losses. The values marked with " $O$ ", " $\triangle$ ", and " $\square$ " were calculated using the value of $8.6 \mathrm{mgN}$ of Ogino et al. ${ }^{6)}$ or 15.7

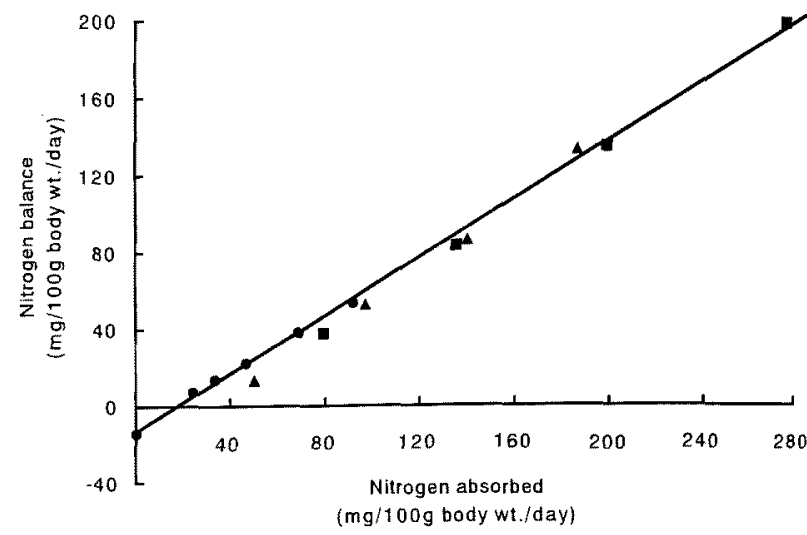

Fig. 12. Relationship between nitrogen absorbed and nitrogen balance in carp fed the casein diet $(\bullet$, Expt. I; $\leftrightarrow$, Expt. II) or the fish meal diet $(\longrightarrow$, Expt. III).

$\mathrm{mgN} / 100 \mathrm{~g}$ body weight/day obtained in the former experiment, ${ }^{4)}$ as the endogenous nitrogen excretion (ENE) value. The non-fecal energy losses increased proportionally to the DE values, based on increased protein intake as already observed by many researchers. ${ }^{17-20)}$

Figure 11 shows the relation between the non-fecal energy/DE rate and the DE intake. In Expts. I, II, and III the DE values for maintenance of energy content of fish body were respectively $24.2,41.4$, and $49.0 \mathrm{kcal} / \mathrm{kg}$ body weight/day as described above. The DE intake in the fish fed at the lowest feeding level in Expt. I was close to the DE requirement for maintenance of energy content of fish body; the non-fecal energy/DE rate therefore remained almost constant independent of the DE intake. On the other hand, in Expts. II and III the non-fecal energy/DE rate increased with decrease of the $D E$ intake in fish receiving less DE than the maintenance requirement for energy content of fish body, suggesting that not only the absorbed dietary amino acids but also tissue proteins were utilized to yield energy to counterbalance the energy requirement. Above this DE intake, the proportion remained constant as observed in Expt. I.

\section{Protein Requirement for Maintenance of Fish Body Pro- tein}

The relationship between the nitrogen balance and the amount of nitrogen absorbed determined by the methods described previously ${ }^{7}$ is presented in Fig. 12. The total value of metabolic fecal and endogenous nitrogen (14 $\mathrm{mgN} / 100 \mathrm{~g}$ body weight/day) obtained in fish fed a protein-free diet by Ogino et $a l^{21)}$ was used for the starved fish at the zero point of nitrogen absorption. Fish were reared at different feeding levels in Expts. I-III, therefore, the calorie intake was insufficient in the fish fed at the low feeding levels, leading to negative nitrogen balance lower than that in fish fed a protein-free diet $(-1.5--34.5 \mathrm{mgN} / 100$ $\mathrm{g}$ body weight/day). Thus, only the positive nitrogen balance was adopted because the negative values were not appropriate for determining the nitrogen requirement.

From the total amount of nitrogen absorbed, the quantity required for maintenance of nitrogen content of fish body was $18-19 \mathrm{mg}$ (113-119 mg protein), corresponding 
to a nitrogen intake of $19-23 \mathrm{mg} / 100 \mathrm{~g}$ body weight/day regardless of fish size and diet. The maximum nitrogen balance was obtained by the nitrogen absorption value of $275 \mathrm{mg} / 100 \mathrm{~g}$ body weight / day in Expt. III. Ogino ${ }^{22)}$ measured the nitrogen balance in carp weighing $87-419 \mathrm{~g}$ fed a casein diet, and reported that the nitrogen intake for maintenance of nitrogen content of fish body was $16-17 \mathrm{mg} /$ $100 \mathrm{~g}$ body weight/day, and that for maximum nitrogen balance was $190-200 \mathrm{mg} / 100 \mathrm{~g}$ body weight/day. The former figure almost agrees with our value, but the latter is lower than our results. These data indicate that nitrogen balance in terms of the protein requirement is influenced by the quality of diet and size of fish.

\section{Conclusion}

Three feeding experiments were conducted to determine the energy content of carp diets needed for maintenance of body weight and activity, and for maximum growth. The digestible energy requirements for maintenance of body weight and activity were $21.6,18.4$, and $35.4 \mathrm{kcal} / \mathrm{kg}$ body weight / day and the corresponding feeding rates were 0.58 , 0.51 , and $1.04 \%$ of body weight/day in fish of 243.2 and $5.6 \mathrm{~g}$ initial body weight fed the casein diet and $3.9 \mathrm{~g}$ initial body weight fed the practical fish meal diet, respectively, the values being significantly influenced by the diets. The $\mathrm{DE}$ requirements for maximum growth were 68,130 , and $172 \mathrm{kcal} / \mathrm{kg}$ body weight $/$ day (at feeding rates of 1.83 , 3.60 , and $5.17 \%$ of body weight / day), being influenced by both diets and fish size. The DE requirements for maintenance of body weight and activity determined based upon feed efficiency were approximately equal to those obtained based upon percent gain. But the DE values required to obtain maximum feed efficiency were lower than those for maximum growth. Dietary energy budgets in carp were also determined in all the experiments by a similar method as that for rainbow trout reported previously.?

\section{References}

1) K. Kouga and T. Suzuki: Enerugyi, Doubutsu no eiyouyoukyuu to haigoushiryou, in "Haigoushiryou Kouza" (ed. by Haigoushiryou Kouza Hensan linkai), The first volume, 2nd ed., Chikusan Syuppan-Sha, Tokyo, 1981, pp. 34-66 (in Japanese).

2) J. R. Brett and T. D. D. Groves: Physiological energetics, in "Fish Physiology" (ed. by W. S. Hoar, D. J. Randall, and J. R. Brett), Vol. 8, Academic press, N.Y., 1979, pp. 279-352.

3) C. Y. Cho, S. J. Slinger, and H. S. Bayley: Bioenergetics of salmonid fishes: Energy intake, expenditure and productivity. Comp. Biochem. Physiol., 73B, 25-41 (1982).

4) T. Watanabe and $M$. Ohta: Endogenous nitrogen excretion and non-fecal energy losses in carp and rainbow trout. Fisheries Sci., 61, 53-60 (1995).
5) T. Watanabe and M. Ohta: Digestible and metabolizable energy of various diets for carp and rainbow trout. Fisheries Sci., 61, 215-222 (1995).

6) C. Ogino, J. Kakino, and M. S. Chen: Protein nutrition in fish-II. Determination of metabolic fecal nitrogen and endogenous nitrogen excretions of carp. Nippon Suisan Gakkaishi, 39, 519-523 (1973).

7) M. Ohta and T. Watanabe: Energy requirements for maintenance of body weight and activity, and for maximum growth in rainbow trout. Fisheries Sci., 62, 731-736 (1996).

8) T. Takeuchi, T. Watanabe, and C. Ogino: Optimum ratio of dietary energy to protein for carp. Nippon Suisan Gakkaishi, 45, 983987 (1979).

9) C. Ogino, J. Y. Chion, and T. Takeuchi: Protein nutrition in fishVI. Effects of dietary energy sources on the utilization of proteins by rainbow trout and carp. Nippon Suisan Gakkaishi, 42, 213-218 (1976).

10) G. Inoue: Hito no tanpakushituhituyouryou, in "Tanpakushitsu Aminosan no Eiyougaku”' (ed. by N. Shimazono and I. Nakagawa) 1st ed., Asakura Shoten, Tokyo, 1964, pp. 289-312 (in Japanese).

11) C. Y. Cho: Effects of dietary protein and lipid levels on energy metabolism of rainbow trout (Salmo gairdneri). Proc. of the 9th International Symp. on Energy Metabolism of Farm Animals, Lillehammer. No. 29, 1982, pp. 176-179.

12) F. W. H. Beamish: Apparent specific dynamic action of largemouth bass, Micropterus salmoides. J. Fish. Res. Board Can., 31, 17631769 (1974).

13) A. Tandler and F. W. H. Beamish: Apparent specific dynamic action (SDA), fish weight and level of caloric intake in largemouth bass, Micropterus salmoides lacepede. Aquaculture, 23, 231-242 (1981).

14) R. J. Pierce and T. E. Wissing: Energy cost of food utilization in the bluegill (Lepomis macrochirus). Trans. Amer. Fish. Soc., No. 1, 38-45 (1974).

15) J. F. Schalles and T. E. Wissing: Effects of dry pellet diets on the metabolic rates of bluegill (Lepomis macrochirus). J. Fish. Res. Board Can., 33, 2443-2449 (1976).

16) R. R. Smith, G. L. Rumsey, and M. L. Scott: Heat increment associated with dietary protein, fat, carbohydrate, and complete diets in salmonids: Comparative energetic efficiency. J. Nutr., 108, 10251032 (1978).

17) J. Savitz: Nitrogen excretion and protein consumption of the bluegill sunfish (Lepomis macrochirus). J. Fish. Res. Bd. Canada, 28, 449-451 (1971).

18) J. Savitz, E. Albanese, M. J. Evinger, and P. Kolasinski: Effect of ration level on nitrogen excretion, nitrogen retention and efficiency of nitrogen utilization for growth in largemouth bass (Micropterus salmoides). J. Fish Biol, 11, 185-192 (1977).

19) F. W. H. Beamish and E. Thomas: Effects of dietary protein and lipid on nitrogen losses in rainbow trout, Salmo gairdneri. Aquaculture, 41, 359-371 (1984).

20) J. Rychly: Nitrogen balance in trout II. Nitrogen excretion and retention after feeding diets with varying protein and carbohydrate levels. Aquaculture, 20, 343-350 (1980).

21) C. Ogino, H. Kawasaki, and H. Nanri: Method for the determination of nitrogen retained in the fish body by the carcass analysis. Nippon Suisan Gakkaishi, 46, 105-108 (1980).

22) C. Ogino: Protein requirements of carp and rainbow trout. Nippon Suisan Gakkaishi, 46, 385-388 (1980). 